\title{
Rethinking Early Iron Age urbanisation in Central Europe: the Heuneburg site and its archaeological environment
}

\author{
Manuel Fernández-Götz \& Dirk Krausse*
}

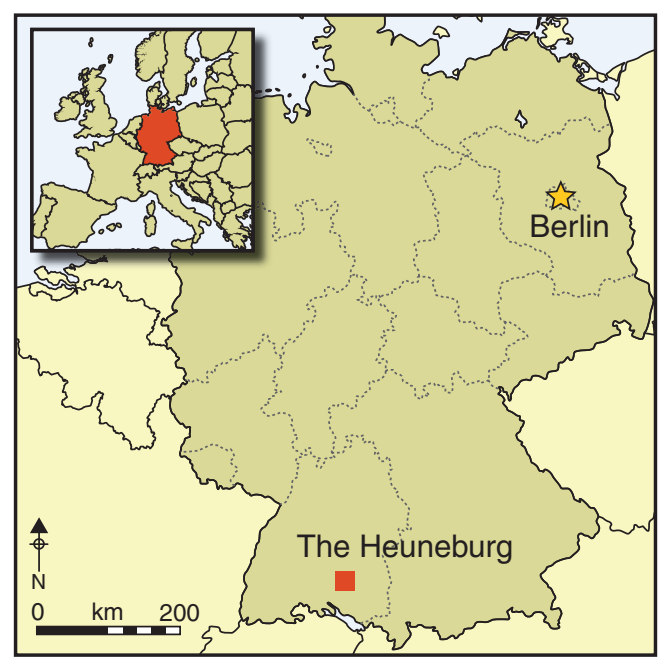
to issues of social hierarchy and status transmission within Late Hallstatt communities. The results provide an entirely new picture of the earliest stages of urbanisation north of the Alps.

Keywords: Central Europe, the Heuneburg, Early Iron Age, centralisation, urbanisation

\section{Centralisation and urbanisation processes north of the Alps}

Traditionally, Late Iron Age oppida have been considered to be the 'first cities north of the Alps' (Collis 1984; Wells 1984). However, large-scale research projects carried out in recent years in Germany and France have started to challenge this long-established view (Biel \& Krausse 2005; Krausse 2008a, 2010; Sievers \& Schönfelder 2012). In the light of new data, today we can maintain that the first urban and proto-urban centres in the region developed between the end of the seventh and the fifth centuries BC in an area stretching from Závist (Drda \& Rybová 2008) in Bohemia, to Mont Lassois (Chaume \& Mordant 2011) and Bourges (Milcent 2007) in central France (Figure 1). Among these 'centres of power' that preceded the oppida by several centuries, the best known and most intensively

Landesamt für Denkmalpflege Baden-Württemberg, Berliner Straße 12, 73728 Esslingen, Germany

(Email:manuelferg@yahoo.es; dirk.krausse@rps.bwl.de) 


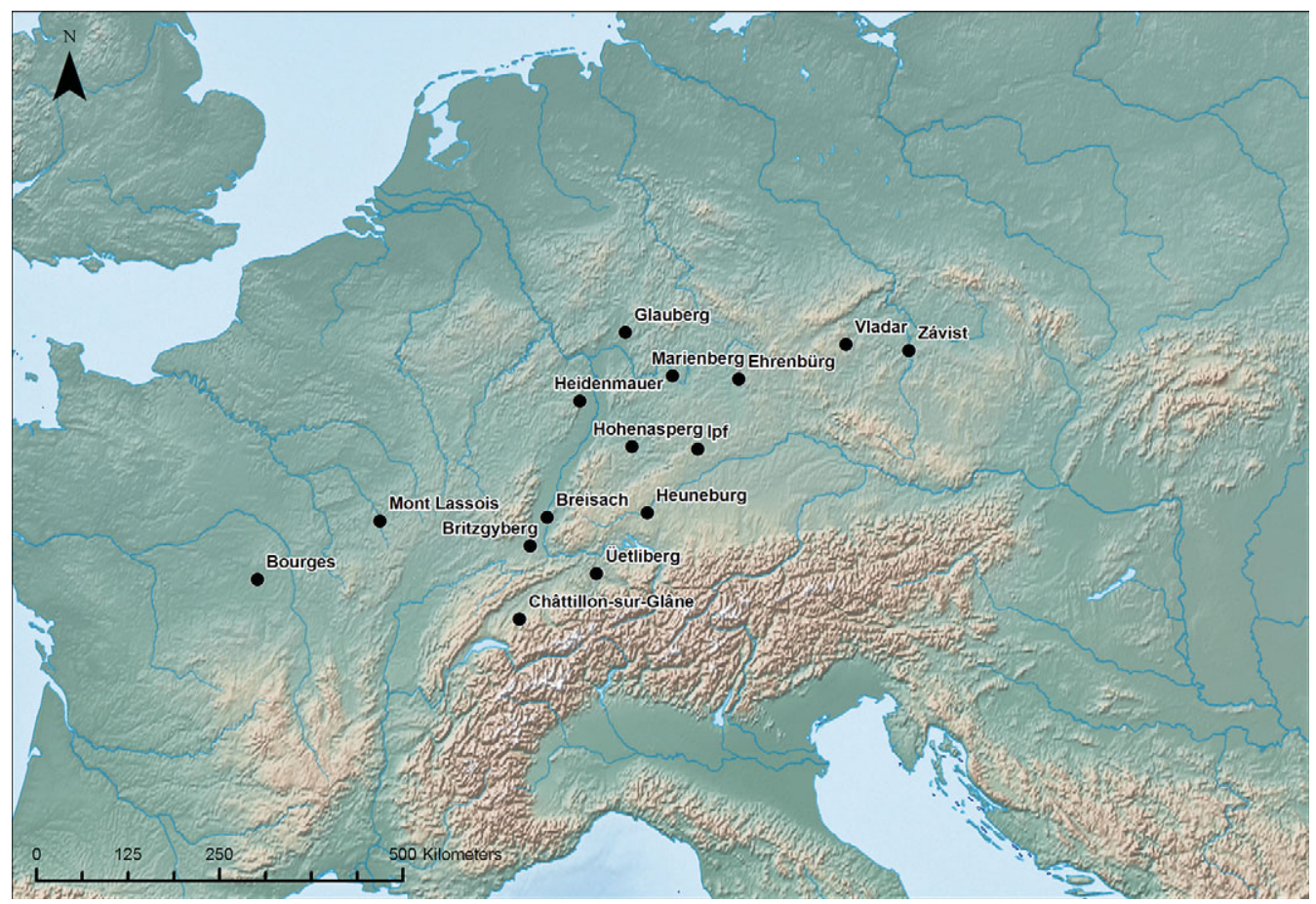

Figure 1. Central places of the seventh to fifth centuries BC from central France to Bohemia (C) C. Steffen, Landesamt für Denkmalpflege).

investigated site is the Heuneburg in southern Germany (Kimmig 1983; Gersbach 1995, 1996; S. Kurz 2010; Krausse \& Fernández-Götz 2012). The results of the excavations leave no room for doubt: this was the site of one of the most important Early Iron Age settlements, a substantial, politically and economically flourishing centre that had extensive connections with areas as distant as Etruria and the Greek colonies (Kimmig 2000).

\section{The Heuneburg project}

Research into the prehistoric landscape around the Heuneburg began in the nineteenth century, when a number of tumuli containing rich grave goods were discovered at GießübelTalhau. The objects found there included gold neck- and armrings, the remains of wagons, bronze vessels and other exceptional objects (Kurz \& Schiek 2002). In 1937-38 extensive excavations were conducted on the Hohmichele mound, which with a height of $13 \mathrm{~m}$ and a diameter of $80 \mathrm{~m}$ is one of the largest tumuli in the whole of Central Europe (Riek \& Hundt 1962). The first systematic excavations on the three hectares of the Heuneburg plateau itself, which overlooks the Danube, began only in the 1950s. It was soon clear that the results would surpass all expectations. The discovery of a mudbrick wall based on Mediterranean prototypes and probably erected around $600 \mathrm{BC}$ was spectacular, and soon attracted international attention. The excavations continued until 1979 and produced further substantial results (Kimmig 1983; Gersbach 1989, 1995, 1996). The archaeological

(C) Antiquity Publications Ltd. 


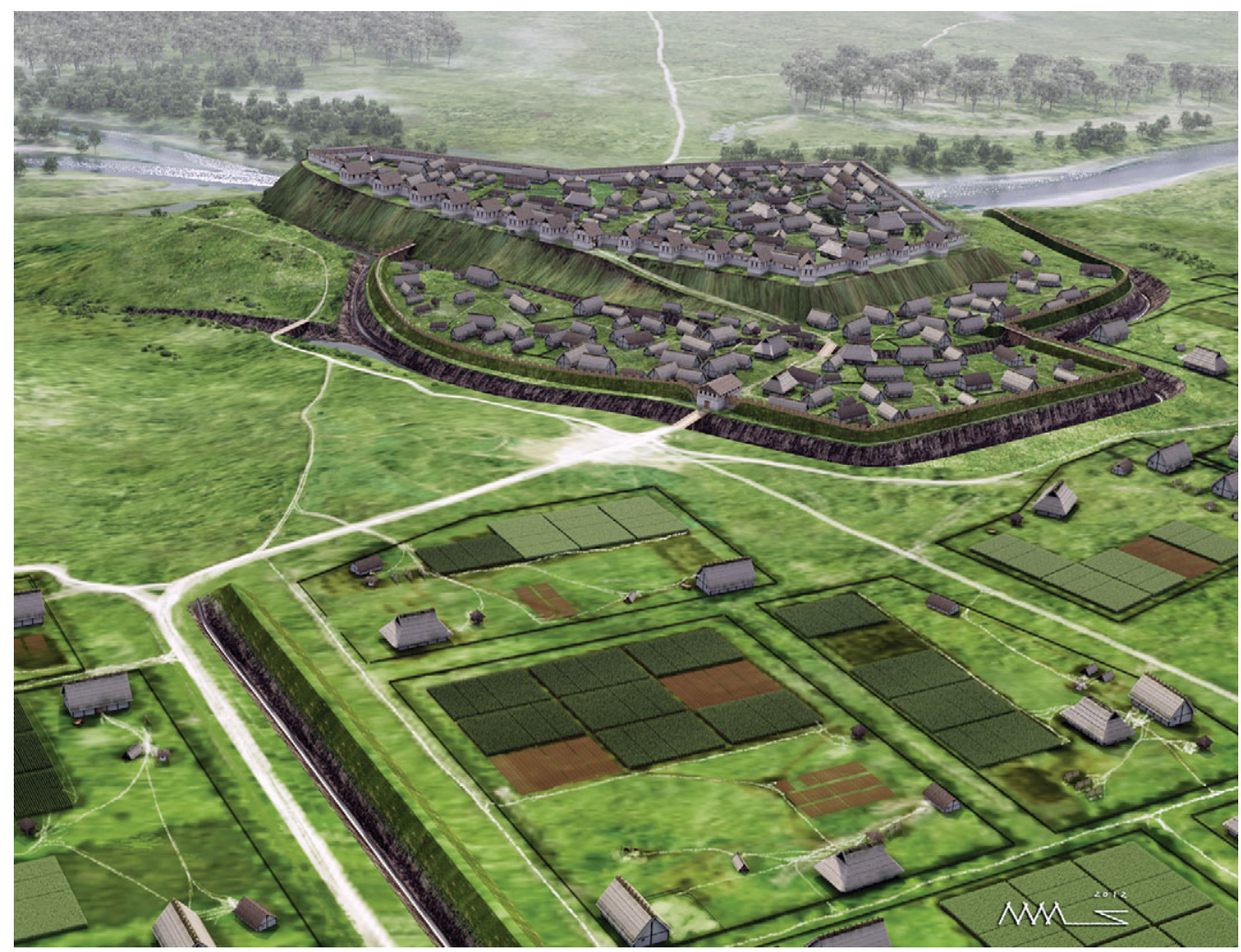

Figure 2. 3D reconstruction of the Heuneburg at the height of its prosperity in the first half of the sixth century BC (C)Landesamt für Denkmalpflege).

material is unusually rich and allows the reconstruction of 14 structural phases during the Late Hallstatt period, together with 10 phases of fortifications, thus providing a remarkable insight into the development of the settlement on the hilltop plateau, which in the Early Iron Age constituted a genuine 'acropolis'. All in all, between 1950 and 1979 approximately one third of the hilltop plateau was systematically excavated and documented.

For many years it was thought that settlement at the Heuneburg was mainly confined to this central hilltop. Although it was clear as early as the 1950 s that there was also an outer settlement beneath the tumuli of the Gießübel-Talhau necropolis, this was thought to cover no more than a few hectares (S. Kurz 2000). However, work in the last 20 years has radically changed this picture. The focus is no longer just on the central hilltop, but has been extended to the surrounding area in the search for further traces of settlement (S. Kurz 2007, 2008, 2010). A combination of field walking, large-scale excavations, geomagnetic prospection and high-resolution airborne LIDAR scans has extended our understanding enormously: old theories have had to be rejected, new ones have been proposed. As a result it can be shown that the central hilltop was only the tip of the iceberg, for the entire settlement at the Heuneburg was in fact divided into three areas: citadel (hilltop plateau), lower town and outer settlement (Krausse \& Fernández-Götz 2012) (Figure 2).

(C) Antiquity Publications Ltd. 


\section{Symbols of power: new data on the fortifications of the lower town}

The establishment of the Priority Programme 'Early Celtic Princely Centres' (2004-2010), with funding of some 8 million euros from the German Research Foundation (DFG), made it possible in 2004 to resume large-scale excavation and prospection at the Heuneburg, as well as at other sites such as the Ipf and the Glauberg (Krause 2008a, 2010). Two teams from the project were involved at the Heuneburg, one conducting investigations in the lower town, while the other team analysed the settlement processes and the structures within the outer settlement, as well as in the surrounding area.

The results produced by the two teams were surprising, and in some cases even sensational. The first discovery that changed the accepted picture completely was the realisation that the defences of the lower town were not medieval, as earlier scholars had thought for many years, but were in fact constructed in the Late Hallstatt period (Bofinger \& Goldner-Bofinger 2008; Stegmaier 2010). The evidence for this came, on one hand, from stratigraphical observations in the area of the present car park at the open-air museum, but above all from the discovery of large quantities of wood in one of the ditches. Dendrochronological analysis provided dates for the timbers of the first quarter of the sixth century BC. They were part of a bridge that was apparently erected around $590 \mathrm{BC}$ and remained in use for at least 10 years, being modified or repaired on several occasions.

In addition to this, fieldwork in the area of the lower town indicated that it was densely settled. The fact that even unsuitable, steeply sloping areas were carefully terraced so that houses could be built there suggests that the population was heavily concentrated and that there was a shortage of space in the settlement. The outcome was the construction of a whole series of artificial terraces that provided level surfaces for the construction of houses and workshops (Bofinger \& Goldner-Bofinger 2008).

A further highlight came with the excavation in 2005-2008 of a monumental stone gate from the Late Hallstatt period. It was erected in the sixth century BC and, like the wall on the plateau, it consisted of mudbricks set on a stone foundation (G. Kurz 2008). The gatehouse was extremely impressive, at more than $16 \mathrm{~m}$ deep and some $10 \mathrm{~m}$ wide, while the opening was narrowed to about $2.5 \mathrm{~m}$ by internal transverse walls. It should be understood as a consciously conceived demonstration of power by the local elite. Quite clearly the gatehouse-integrated as it was into the $5 \mathrm{~m}$ high rampart, and set behind a ' $\mathrm{V}$ '-shaped ditch some $14 \mathrm{~m}$ wide, up to $6 \mathrm{~m}$ deep and crossed by a wooden bridge-was designed to make as monumental an impression as was possible (Figure 3).

\section{Farmsteads and hillforts: the outer settlement and beyond}

The discoveries made in the outer settlement are also of fundamental importance for our understanding of the Heuneburg. The new excavations and surveys revealed that at least in the first half of the sixth century BC an enormous area of some 100ha to the north, west and south-west of the hilltop plateau was taken up by closely spaced farmsteads enclosed by rectangular palisades (S. Kurz 2008, 2010). This huge outer settlement was divided into smaller quarters by an extensive system of banks and ditches. These in turn enclosed various 'properties' of between 1 and 1.5 ha that were surrounded by massively built timber fences.

(C) Antiquity Publications Ltd. 


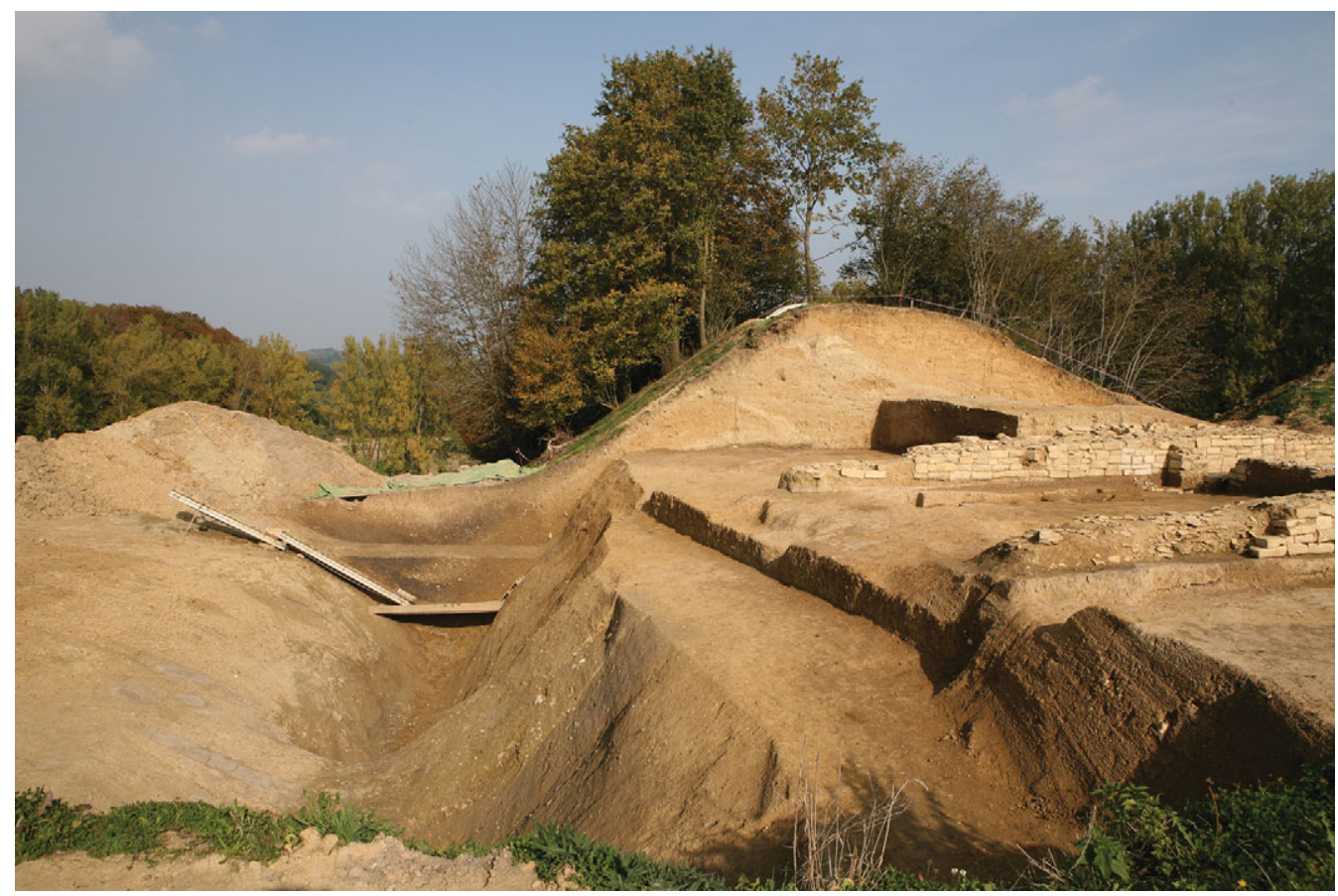

Figure 3. Monumental stone gate forming the entrance to the lower town of the Heuneburg: profile through the bank, stone gate pedestal and ditch (C) Landesamt für Denkmalpflege).

Those parts of the outer settlement that were suitable for settlement will have provided sufficient space for some 50 such units (Figure 4). The majority of the various groups who had come together during a process of synoecism would have lived here. The division of the outer settlement into separate quarters may also be evidence for the existence of different kinship groups, each inhabiting one of these quarters.

The second project team not only worked in the outer settlement, but also had the task of investigating the surrounding area (S. Kurz 2008). A whole series of Hallstatt period hillforts are known within 20km of the Heuneburg: Alte Burg, Große Heuneburg, Bussen, Ennetacher Berg and Hochberg. Several other fortified sites (Landauhof, Österberg, Hagelsburg) are at present undated, but may also be contemporary (Figure 5). This unusual concentration of hilltop settlements in the vicinity of the Heuneburg clearly suggests that they were in some way related. This is confirmed by finds from the dated hillforts: most of them are from the early Late Hallstatt period (Ha D1), in other words, precisely the same period when the Heuneburg and the outer settlement were at their greatest extent. As yet, however, we are not in a position to say whether the smaller hillforts developed independently of the Heuneburg, or were in fact established and operated from it. The most likely assumption is that they were subordinate to the Heuneburg; in other words, that there was a hierarchy of settlements, with the Heuneburg as a supra-regional centre of power and a number of dependent hillforts within its territory.

The only one of these small hillforts to have been systematically investigated in recent years is the Alte Burg near Langenenslingen. The fieldwork led to a number of important

(C) Antiquity Publications Ltd. 
discoveries. First, it was established that the hilltop spur of the Alte Burg had been intensively landscaped and reshaped during the Hallstatt or Early La Tène periods. Secondly, in the

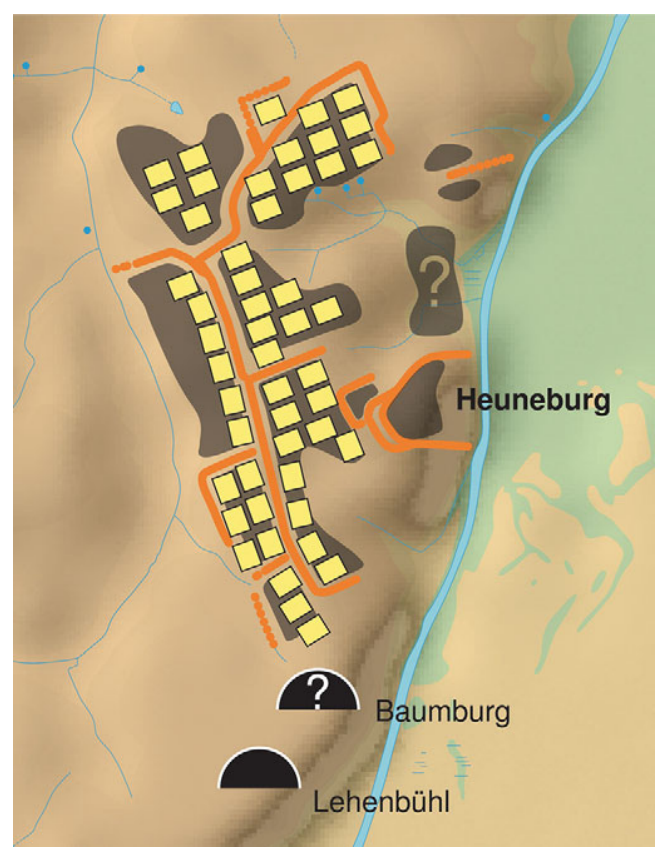

Figure 4. Division of the settlement areas in the outer settlement into smaller quarters, each containing several farmsteads (C) S. Kurz, Landesamt für Denkmalpflege). centre of the site there was a shaft in which not only ceramics, charred wood and animal bones had been deposited, but also large numbers of human bones. Deposition persisted well into the La Tène period and provides indisputable evidence of ritual activity. Quite clearly this was a sacred place that continued to be frequented long after the end of the Late Hallstatt Heuneburg.

\section{The Heuneburg: an urban centre}

About the middle of the fifth century BC Herodotus of Halicarnassus, the Greek 'father of history', wrote in his famous work The Histories (II, 33; Godley 1921) that: "The Istros (Danube) river arises among the Celts and the polis of Pyrene, cutting Europe across the middle". It has repeatedly been suggested that Pyrene, the polis mentioned by Herodotus, is to be identified with the Heuneburg. Although that remains only a hypothesis, and some scholars have even proposed that the name Pyrene was confused with the Pyrenees, the site itself was indisputably quite exceptional.

The new discoveries made in the last 10 years have radically changed our traditional image of the Heuneburg: instead of a small hillfort covering only a few hectares (Kimmig 1969, 1983), we would have been looking in the first half of the sixth century BC at an enormous settlement of 100 ha with an estimated population of around 5000 inhabitants (S. Kurz 2010; Krausse \& Fernández-Götz 2012). Moreover, during the Late Hallstatt period the Heuneburg constituted an important production and distribution centre, where not only pottery but other artisanal wares were manufactured, including fibulae and textiles (Kimmig 1983; Gersbach 1995). The settlement is also significant from an archaeozoological point of view; recent stable isotope analysis shows that during the mudbrick wall period, with its highly concentrated population, a significant proportion of the animals were imported from a distance of 50-60km (Schatz \& Stephan 2008).

Both the Heuneburg and other contemporary sites such as Hohenasperg, Bourges or Mont Lassois should no longer be described as small 'princely centres', but rather as the first urban or proto-urban centres of temperate Europe, ruled by kings and aristocrats whose power and social position is reflected in rich burials such as those at Hohmichele, Bettelbühl, Hochdorf, Grafenbühl, Sainte-Colombe or Vix (Biel \& Krausse 2005; Milcent 2007; Krausse 2008a, 2010; Chaume \& Mordant 2011). These settlements would have constituted the focal

(C) Antiquity Publications Ltd. 


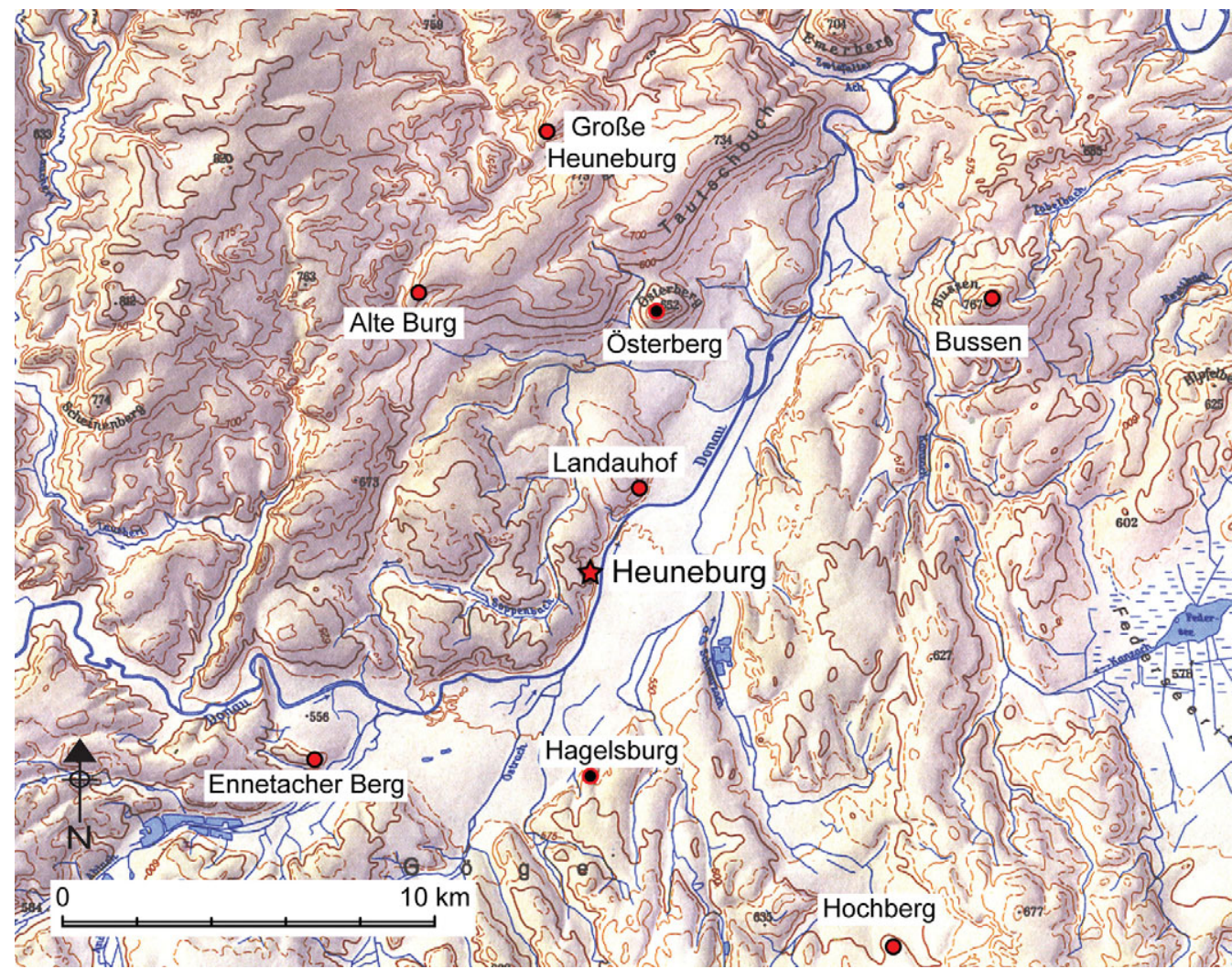

Figure 5. Hillforts in the vicinity of the Heuneburg (C)Landesamt für Denkmalpflege).

points of different entities that might have maintained relations of the type proposed in the peer polity interaction model (Renfrew \& Cherry 1986). This is also suggested by their spatial distribution (Härke 1979). Trade with the Mediterranean was not the prime mover of cultural change (Frankenstein \& Rowlands 1978; Wells 1984), but rather a consequence of demographic growth and increasing internal inequalities; power and status would have depended mainly on land ownership and the control of local production (Gosden 1985).

On the basis of the new evidence, we can conclude that the Heuneburg constituted the central place of an important Early Iron Age polity, comparable in power and influence to Etruscan city-states of the Archaic period such as Tarquinia, Veii or Orvieto (Riva 2010). Given its early date, the Heuneburg has often been described as the 'first city north of the Alps'. In this article we follow Smith's (2007: 4) definition of 'urban settlements' as "centres whose activities and institutions-whether economic, administrative or religious-affect a larger hinterland". According to Smith, there are two principal ways to define a city: the demographic definition, based on criteria such as permanence, large population size or social heterogeneity; and the functional definition, where the settlement in question has to be the setting for people and institutions that impacted a larger realm (Smith 2010; see also Marcus \& Sabloff 2008). In this context, the Heuneburg seems to qualify for urban status on either definition, at least for the period of the mudbrick wall (c. 600/590-540/530 BC). The huge

(C) Antiquity Publications Ltd. 
extent of the settlement at $100 \mathrm{ha}$, the size of population (very large for its time), significant status differences and craft specialisation all fit the demographic definition. As for the functional definition, the main urban functions seem to be craft production and exchange, which presumably served a larger hinterland; and political status as suggested by the astonishing concentration of sumptuous burials around the settlement, and perhaps also by the monumental walls, towers and gates which might be signals of a political capital. Whereas scholars working on the Mediterranean world make widespread use of the terms 'towns' and 'cities' to designate a wide range of first millennium BC settlements, the use of such categories is still much discussed for temperate Europe. However, this reluctance-which is ultimately based on the unacceptable distinction between a 'civilised' south and a 'barbarian' northhas often more to do with modern prejudices than with the past reality of ancient societies. Building on the insights above, we would like to propose a context-dependent definition of 'city' which recognises the high levels of variation that often exist between and within different urban traditions: 'a numerically significant aggregation of people permanently living together in a settlement which fulfils central place functions for a wider territory'.

\section{Placing the dead: the ancestral landscape around the Heuneburg}

From the beginning, the settlement at the Heuneburg was surrounded by numerous tumuli which served as the last resting place for members of the social elite and their relatives (e.g. Hohmichele, Bettelbühl, Rauher Lehen; see Kurz \& Schiek 2002). The monuments that composed this extensive 'landscape of ancestors' functioned as a mnemonic system that was central to issues of kinship, territoriality and social memory (Arnold 2010). As in most ancient societies, death, identity and social memory would have been fundamentally interrelated. In this context, the placing of tumuli in the landscape could imply a strategy of tying the dead of particular households or lineages to specific parcels of land. Moreover, the landscape would have played a key role in the construction and maintenance of social memory and power relationships both within and between groups (Parker Pearson 1999).

It is interesting to note that the burials of the early phase were situated at some distance from the settlement at the Heuneburg. Many of the large mounds and sumptuous burials are arranged in extensive cemeteries that include not only rich, but also normal or simply furnished graves (Kurz \& Schiek 2002). An example of a rich chamber burial from the period is wagon burial 6 from the Hohmichele mound, which must date to about the first quarter of the sixth century BC (Riek \& Hundt 1962). Unfortunately, most of the central graves in the mounds were robbed in ancient times, so that most of the richest burials have probably been lost (Kümmel 2009).

It is for precisely this reason that the latest results from the Bettelbühl necropolis, $2.5 \mathrm{~km}$ south-east of the Heuneburg in the Danube valley, are of enormous scholarly interest. In 2005 the secondary burial of a two- to four-year-old girl was found in Mound 4. It was furnished with two gold-plated fibulae and two gold pendants, and is one of only a handful of rich child burials of the Hallstatt culture. Such a wealthy burial for a young child is an indication that at this time the concept of inherited status was becoming established at the Heuneburg, for it is generally assumed that the children will hardly have been buried so conspicuously as a result of their own actions.

(C) Antiquity Publications Ltd. 


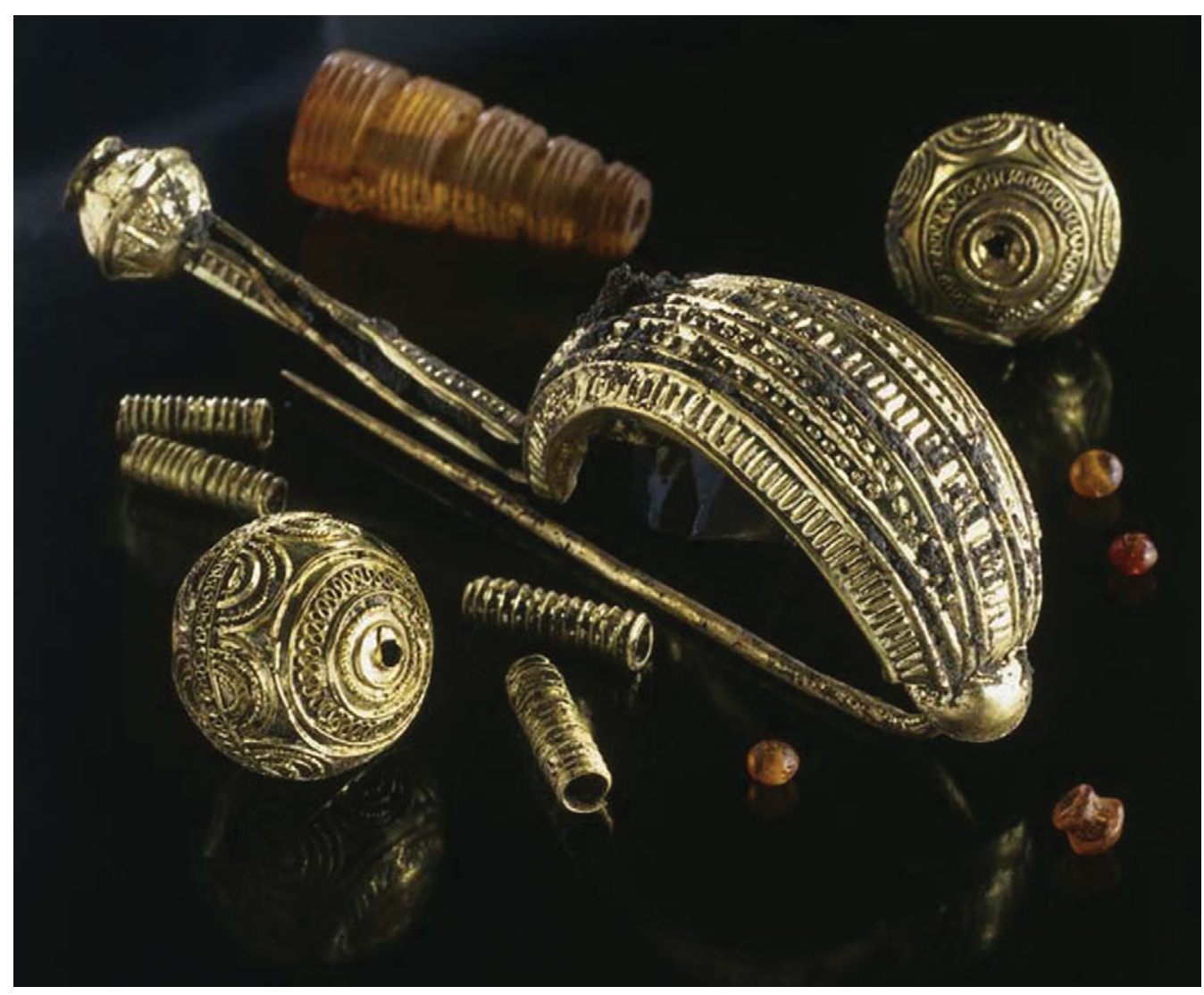

Figure 6. Selection of finds from the newly discovered rich burial in the Bettelbühl necropolis (C)Landesamt für Denkmalpflege).

But the main highlight is the central burial in the same mound (Bettelbühl 4), which was removed at the end of December 2010 as an 80-tonne block. It is a shaft grave with a $4.6 \times 3.6 \mathrm{~m}$ timber chamber; the floorboards and some of the side planks are excellently preserved thanks to the extreme humidity of the soil. Although excavation in the laboratory has not yet been completed, it is already clear that this is the unrobbed burial of a woman (Krausse \& Ebinger-Rist 2011). The gold jewellery and the fibulae are very similar to the gold objects in the child's grave, and we must assume that there were probably strong social connections between the two rich burials (Figure 6). So far some 30 gold objects (earrings, fibulae, pendants), as well as more than 100 pieces of amber have been recovered. Dendrochronological analysis places the grave in the early sixth century BC, meaning that it is one of the very oldest richly furnished female burials known from the Early Iron Age.

\section{An eventful history}

It is important to realise that the extent and the significance of the Late Hallstatt Heuneburg by no means remained unchanged over the period of less than 200 years during which it

(C) Antiquity Publications Ltd. 
was occupied. On the contrary, the various structural phases, burnings and restructurings are testimony to an eventful history and dynamic social change. As a result of extensive surveys, we can now assume that in the seventh and sixth centuries BC there was a scatter of farms and hamlet-sized agricultural settlements in the region around the Heuneburg (S. Kurz 2007). As the farming settlements prospered, so too grew the population, and local elites developed. It must have been the circle of the most important families and settlement groups who were responsible for initiating the construction of the Heuneburg in the course of the second half of the seventh century BC. The heads of different households and lineage groups must have joined together in a process that led to the construction of the outer settlement at the Heuneburg.

After a first phase of settlement and fortification based on a traditional pattern, sometime around or soon after $600 \mathrm{BC}$, a wall was built around the three-hectare hilltop plateau. This wall was unique north of the Alps, consisting of mudbricks set on a stone base, and along the north and west faces rectangular towers were incorporated into it. The structure was clearly inspired by Mediterranean prototypes. In contrast to the outer settlement, during the first half of the sixth century BC the citadel at the Heuneburg was densely built up with relatively uniform, small buildings set in rows, some of which served as workshops (Gersbach 1989, 1995). During the mudbrick wall period an enormous structure covering $320 \mathrm{~m}^{2}$, containing several rooms, was erected outside the citadel on the later site of Mound 4 of the Gießübel-Talhau necropolis. This building shows structural similarities with the Etruscan palaces of Murlo and Acquarossa (Verger 2008).

A dramatic break in the history of the Heuneburg came after the mid-sixth century BC in association with a devastating fire. Although it is difficult to determine the exact causes of the catastrophe, the most likely possibilities are external attack or internal conflict. Whatever may have happened, most of the material from the recent excavations within the enormous outer settlement dates to the period of the mudbrick wall, and material from the end of the sixth and the beginning of the fifth centuries BC is restricted to just a few isolated areas (S. Kurz 2008, 2010). This may indicate that the outer settlement was abandoned soon after the middle of the sixth century BC, and that the Heuneburg was fundamentally restructured. This hypothesis is confirmed by the Gießübel-Talhau cemetery, which dates from 540/530 BC and was placed over the remains of the outer settlement. The large tumuli of the Gießübel-Talhau necropolis are to be interpreted as an isolated aristocratic cemetery; they were not incorporated into a larger necropolis, but instead emphasise the special social status of a ruling elite at the Heuneburg.

At about the same time as the outer settlement was abandoned and the Gießübel-Talhau necropolis was initiated, a fundamental change in the architecture of the citadel fortification can be observed. There is general agreement that the end of the mudbrick wall is also to be dated to about $540 / 530 \mathrm{BC}$, after which there was a reversion to a traditional earth and timber rampart. The buildings in the citadel underwent a complete reorganisation at the same time. Instead of the rows of relatively uniform houses of the mudbrick phase, buildings of varying size and function now appear, including prestigious structures up to $400 \mathrm{~m}^{2}$ (Gersbach 1996). These are open to a number of interpretations, including regia, aristocratic residences, or assembly halls. At the same time, there was an intensification of settlement activity in the lower town. Here, densely built terraced areas were occupied in the (C) Antiquity Publications Ltd. 


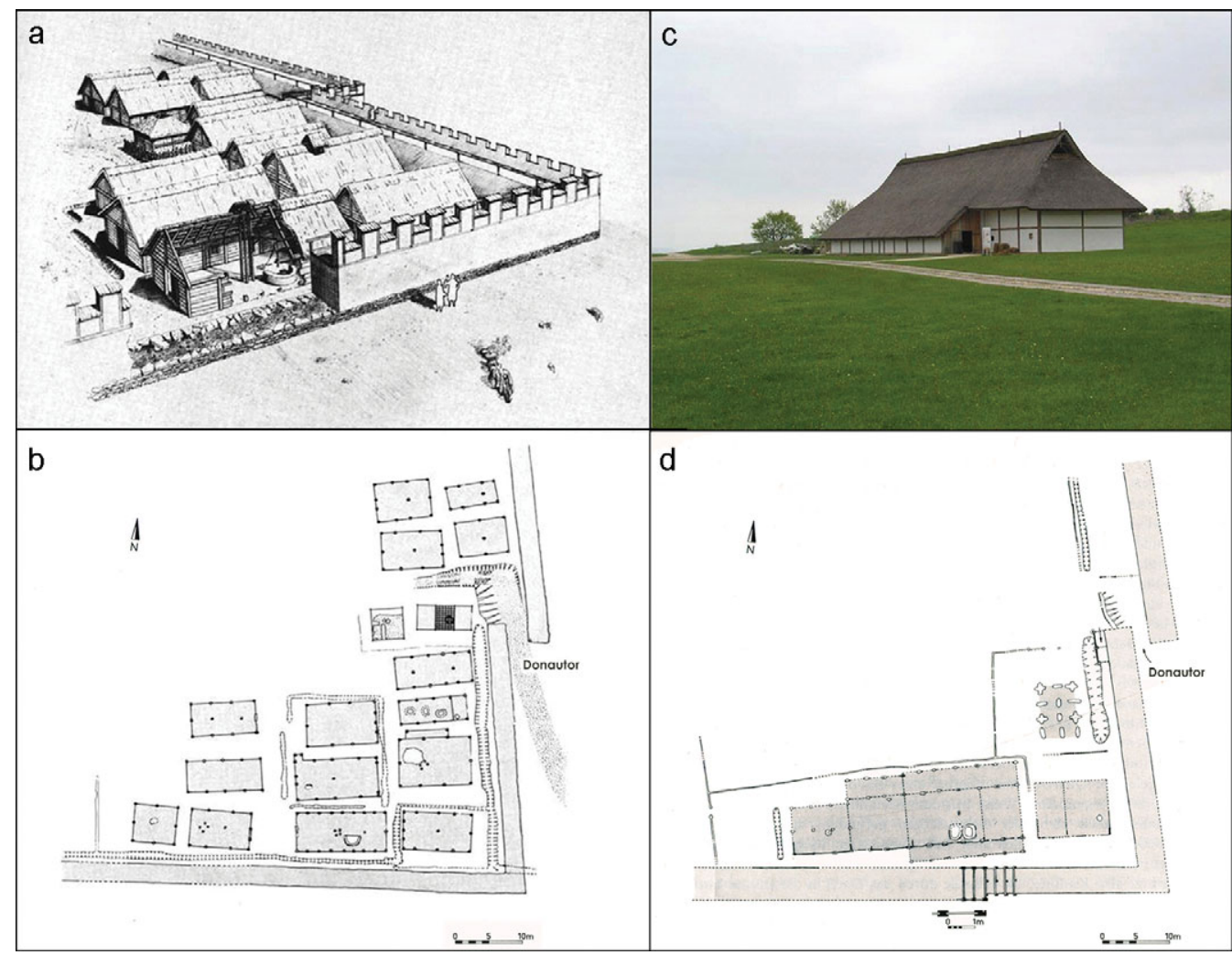

Figure 7. South-east corner of the citadel. Left: conjectural reconstruction (a) and plan (b) of buildings during the mudbrick wall phase; right: photograph (c) of the reconstructed monumental house in the open-air museum and plan (d) of buildings following the mudbrick phase (c) Landesamt für Denkmalpflege).

last quarter of the sixth and the early fifth centuries BC. They have produced large quantities of finds, and apparently housed artisans and other elements of the population who were involved in service activities (Bofinger \& Goldner-Bofinger 2008). To sum up, we can say that during the mudbrick phase the buildings within the citadel were mostly uniform and set closely together, while outside it structures were more scattered and varied. But in the following period this was reversed, with less dense and more varied construction within the citadel, while outside in the lower town, structures were more crowded and the architecture was probably more uniform (Krausse \& Fernández-Götz 2012) (Figure 7). Interestingly, most of the Mediterranean imports, including several Greek vases, belong to the period after the end of the mudbrick wall (Kimmig 2000).

\section{Conclusions: rethinking Iron Age urbanisation}

The spectacular results of the work carried out in recent years serve to indicate that the political and demographic dimensions of Central European societies in the sixth and fifth centuries BC have hitherto been under- rather than overestimated (Krausse 2008a, 2010).

(C) Antiquity Publications Ltd. 


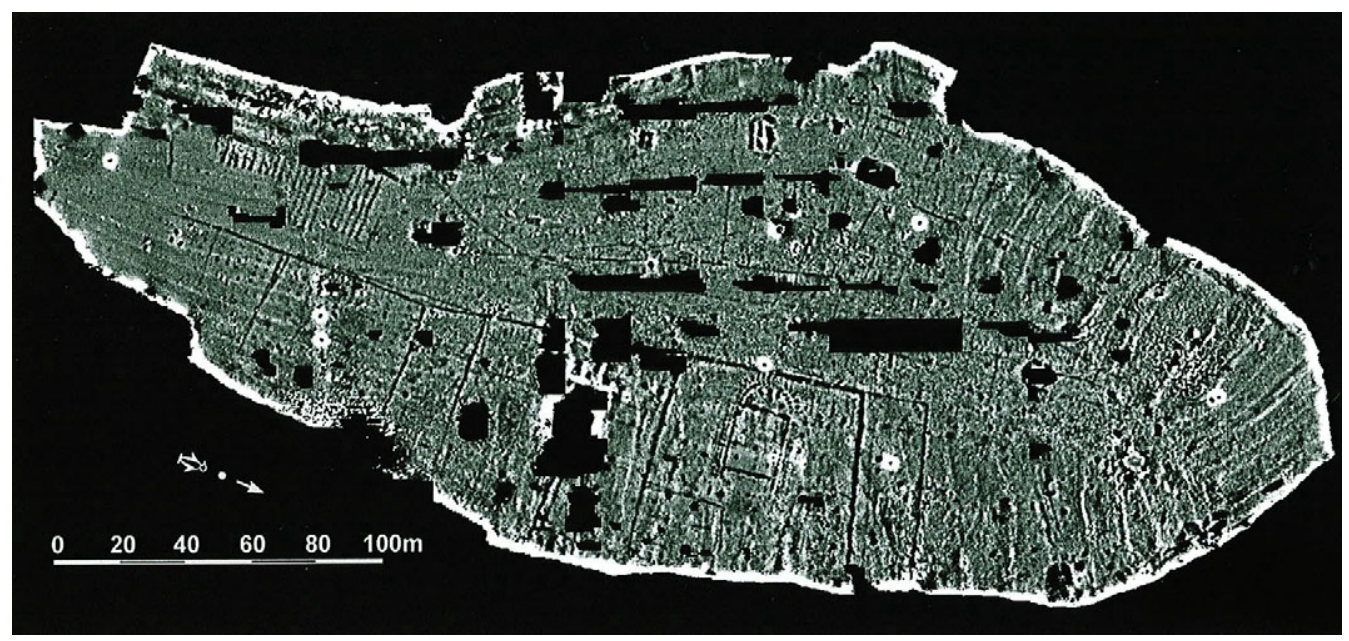

Figure 8. Mont Lassois: geomagnetic plan of the plateau of Saint-Marcel, showing the well-organised structure of the settlement (after Chaume \& Mordant 2011).

There is a great deal of evidence that during the Hallstatt and Early La Tène periods numerous local and regional groups were integrated into larger collectives. With regard to the 'social typologies' that have been defined by authors such as Johnson \& Earle (2000), the communities which were established around centres of power such as the Heuneburg, Hohenasperg, Mont Lassois or Bourges can best be placed at the transition from complex chiefdoms to early states, and in a few concrete cases the latter term is in fact particularly apposite.

Within just a few decades these power centres, with settlements covering dozens or even hundreds of hectares and populations in the thousands, could attain enormous dimensions. The 100ha of the Heuneburg during the mudbrick phase, or the several hundred hectares at Bourges, are impressive examples of the process (Biel \& Krausse 2005; Milcent 2007; Krausse 2008a, 2010). Monumental fortifications, secular, sacred and funerary architecture, craft quarters and Mediterranean imports all bear testimony to the manifold functions of such sites (Figure 8). Their dominance and symbol-laden significance is manifested in the imposing defences with banks, ditches, walls and gates found, for example, at the Heuneburg and Mont Lassois. Sanctuaries related to ancestor worship, such as the heroon and the $350 \mathrm{~m}$ processional way at the Glauberg, or the enclosure of Vix 'Les Herbues' at Mont Lassois, are evidence for religious and cult aspects. Artisanal and technical, economic and mercantile functions are reflected in the presence of workshops for specialised craftsmen or even entire quarters for them, as at Bourges, as well as in imported goods. Finally, the presence of sumptuous elite burials in the environs of central places (Hohmichele, Bettelbühl, Gießübel-Talhau, Hochdorf, Grafenbühl, Kleinaspergle, Sainte-Colombe, Vix, etc.) is testimony, among other things, to political and administrative functions.

It is important to note, however, that this early process of centralisation and urbanisation was followed by a phase of decentralisation that set in at different times in different areas, and can be seen as a specific instance of the non-linear character of events (Krausse 2008b).

(C) Antiquity Publications Ltd. 
Both the Heuneburg and Mont Lassois were more or less abandoned in the first half or middle of the fifth century BC without any obvious explanation. Furthermore, it must be emphasised that throughout the whole of the Iron Age there were not only strongly hierarchical societies, but also other communities, often nearby, in which the structures of power were less clearly defined and which present evidence for a more heterarchical and decentralised landscape (Hill 2006). In other words, there was no such thing as the Iron Age society, nor a continual evolutionary development from simpler to more complex forms of organisation. Rather, there were various Iron Age societies and multi-layered, changing and dynamic cycles of centralisation and decentralisation (Fernández-Götz forthcoming). In the area immediately north of the Alps, a new trend towards centralisation can be observed in the late third and second centuries BC, leading to the development of the oppida of the Late La Tène period (Collis 1984; Salač 2012). Although these later sites present a much wider geographical distribution, and in many cases also a larger surface area than the Late Hallstatt/Early La Tène 'Fürstensitze', the differences between the two settlement forms seem to be less marked than has traditionally been thought (Sievers 2010). Exploring the diversity and similarity of Iron Age urbanisation processes across time and space remains, therefore, a task for future research.

\section{References}

ARNOLD, B. 2010. Memory maps: the mnemonics of Central European Iron Age burial mounds, in K.T. Lillios \& V. Tsamis (ed.) Material mnemonics: everyday memory in prehistoric Europe: 147-73. Oxford: Oxbow.

Biel, J. \& D. Krausse (ed.). 2005. Frühkeltische Fürstensitze. Alteste Städte und Herrschaftszentren nördlich der Alpen? (Archäologische Informationen aus Baden-Württemberg 51). Esslingen: State Office for Cultural Heritage Baden-Württemberg.

BOFIngER, J. \& A. GOLDNER-BOFINGER. 2008. Terrassen und Gräben-Siedlungsstrukturen und Befestigungssysteme der Heuneburg-Vorburg, in D. Krausse (ed.) Frühe Zentralisierungs- und Urbanisierungsprozesse. Zur Genese und Entwicklung frühkeltischer Fürstensitze und ihres territorialen Umlandes (Forschungen und Berichte zur Vor- und Frühgeschichte in Baden-Württemberg 101): 209-27. Stuttgart: Konrad Theiss.

Chaume, B. \& C. Mordant (ed.). 2011. Le complexe aristocratique de Vix. Dijon: PU Dijon.

COLLIS, J. 1984. Oppida: earliest towns north of the Alps. Sheffield: University of Sheffield.

Drda, P. \& A. RYBOVA. 2008. Akropole na hradišti Závist v 6.-4. stol. př. Kr (Památky archeologické_-Supplementum 19). Praha: Archeologický ústav Akademie věd České republiky.

FERNÁNDEZ-GÖTZ, M. Forthcoming. Identity and power: the transformation of Iron Age societies in northeast Gaul. Amsterdam: Amsterdam University Press.
Frankenstein, S. \& M.J. Rowlands. 1978. The internal structure and regional context of Early Iron Age society in south-western Germany. Bulletin of the Institute of Archaeology 15: 73-112.

GersbaCH, E. 1989. Ausgrabungsmethodik und Stratigraphie der Heuneburg (Römisch-Germanische Forschungen 45). Mainz: von Zabern.

- 1995. Baubefunde der Perioden IVc-IVa der Heuneburg (Römisch-Germanische Forschungen 53). Mainz: von Zabern.

- 1996. Baubefunde der Perioden IIIb-Ia der Heuneburg (Römisch-Germanische Forschungen 56). Mainz: von Zabern.

Godley, A.D. 1921. Herodotus, The Histories. London: William Heinemann.

GosDen, C. 1985. Gifts and kin in Early Iron Age Europe. Man 20: 475-93.

HÄRKE, H. 1979. Settlement types and settlement patterns in the West Hallstatt province (British Archaeological Reports international series 57). Oxford: BAR.

HiLl, J.D. 2006. Are we any closer to understanding how later Iron Age societies worked (or did not work)?, in C. Haselgrove (ed.) Celtes et Gaulois, l'archéologie face à l'histoire. 4: les mutations de la fin de l'âge du fer (Collection Bibracte 12/4): 169-79. Glux-en-Glenne: Centre archéologique européen.

Johnson, A.W. \& T. EARLE. 2000. The evolution of human societies: from foraging group to agrarian state. Stanford (CA): Stanford University Press. 
KImmig, W. 1969. Zum Problem späthallstättischer Adelssitze, in K.-H. Otto \& J. Herrmann (ed.) Siedlung, Burg und Stadt. Studien zu ihren Anfängen. Festschrift für Paul Grimm: 95-113. Berlin: Deutsche Akademie der Wissenschaften zu Berlin.

- 1983. Die Heuneburg an der oberen Donau. Stuttgart: Konrad Theiss.

- (ed.). 2000. Importe und mediterrane Einflüsse auf der Heuneburg (Römisch-Germanische Forschungen 59). Mainz: von Zabern.

Krausse, D. (ed.). 2008a. Frühe Zentralisierungs- und Urbanisierungsprozesse. Zur Genese und Entwicklung frühkeltischer Fürstensitze und ihres territorialen Umlandes (Forschungen und Berichte zur Vor- und Frühgeschichte in Baden-Württemberg 101). Stuttgart: Konrad Theiss.

- 2008b. Etappen der Zentralisierung nördlich der Alpen. Hypothesen, Modelle, Folgerungen, in D. Krausse (ed.) Frühe Zentralisierungs- und Urbanisierungsprozesse. Zur Genese und Entwicklung frühkeltischer Fürstensitze und ihres territorialen Umlandes (Forschungen und Berichte zur Vor- und Frühgeschichte in Baden-Württemberg 101): 435-450. Stuttgart: Konrad Theiss.

- (ed.). 2010. "Fürstensitze” und Zentralorte der frühen Kelten (Forschungen und Berichte zur Vor- und Frühgeschichte in Baden-Württemberg 120). Stuttgart: Konrad Theiss.

Krausse, D. \& N. Ebinger-Rist. 2011. Die Keltenfürstin von Herbertingen. Denkmalpflege in Baden-Württemberg 40: 202-207.

Krausse, D. \& M. FernándeZ-Götz. 2012. Die Heuneburg. Neue Forschungen zur Entwicklung einer späthallstattzeitlichen Stadt, in Die Welt der Kelten. Zentren der Macht-Kostbarkeiten der Kunst: 116-23. Ostfildern: Thorbecke.

KÜMMEL, C. 2009. Ur- und frühgeschichtlicher Grabraub (Tübinger Schriften zur Ur- und

Frühgeschichtlichen Archäologie 9). Münster: Waxmann.

KuRZ, G. 2008. Ein Stadttor und Siedlungen bei der Heuneburg (Gemeinde HerbertingenHundersingen, Kreis Sigmaringen), in D. Krausse (ed.) Frühe Zentralisierungs- und Urbanisierungsprozesse. Zur Genese und Entwicklung frühkeltischer Fürstensitze und ihres territorialen Umlandes (Forschungen und Berichte zur Vor- und Frühgeschichte in Baden-Württemberg 101): 185-208. Stuttgart: Konrad Theiss.

Kurz, S. 2000. Die Heuneburg-Aussensiedlung. Befunde und Funde (Forschungen und Berichte zur Vor- und Frühgeschichte in Baden-Württemberg 72). Stuttgart: Konrad Theiss.
- 2007. Untersuchungen zur Entstehung der Heuneburg in der späten Hallstattzeit (Forschungen und Berichte zur Vor- und Frühgeschichte in Baden-Württemberg 105). Stuttgart: Konrad Theiss.

- 2008. Neue Forschungen im Umfeld der Heuneburg, in D. Krausse (ed.) Frühe Zentralisierungs- und Urbanisierungsprozesse. Zur Genese und Entwicklung frühkeltischer Fürstensitze und ihres territorialen Umlandes (Forschungen und Berichte zur Vor- und Frühgeschichte in Baden-Württemberg 101): 163-83. Stuttgart: Konrad Theiss.

- 2010. Zur Genese und Entwicklung der Heuneburg in der späten Hallstattzeit, in D. Krausse (ed.) "Fürstensitze" und Zentralorte der frühen Kelten (Forschungen und Berichte zur Vor- und Frühgeschichte in Baden-Württemberg 120): 239-56. Stuttgart: Konrad Theiss.

KURZ, S. \& S. SCHIEK. 2002. Bestattungsplätze im Umfeld der Heuneburg (Forschungen und Berichte zur Vor- und Frühgeschichte in Baden-Württemberg 87). Stuttgart: Konrad Theiss.

Marcus, J. \& J. SABloff (ed.). 2008. The ancient city: new perspectives on urbanism in the Old and New World. Santa Fe (NM): SAR.

Milcent, P.-Y. (ed.). 2007. Bourges-Avaricum: un centre proto-urbain celtique du Ve siècle av. J.-C. Bourges: Bituriga.

Parker Pearson, M. 1999. The archaeology of death and burial. Stroud: Sutton.

Renfrew, C. \& J.F. Cherry (ed.). 1986. Peer polity interaction and socio-political change. Cambridge: Cambridge University Press.

Riek, G. \& H.-J. HundT. 1962. Der Hohmichele. Ein Fürstengrabhügel der späten Hallstattzeit bei der Heuneburg (Römisch-Germanische Forschungen 25). Berlin: de Gruyter.

RIVA, C. 2010. The urbanisation of Etruria. Cambridge: Cambridge University Press.

SALAČ, V. 2012. Les oppida et les processus d'urbanisation en Europe centrale, in S. Sievers \& M. Schönfelder (ed.) Die Frage der Protourbanisation in der Eisenzeit: 319-45. Bonn: Habelt.

Schatz, K. \& E. Stephan. 2008. Archäozoologie frühkeltischer Faunenfunde, in D. Krausse (ed.) Frühe Zentralisierungs- und Urbanisierungsprozesse. Zur Genese und Entwicklung frühkeltischer Fürstensitze und ihres territorialen Umlandes (Forschungen und Berichte zur Vor- und Frühgeschichte in Baden-Württemberg 101): 349-66. Stuttgart: Konrad Theiss.

(C) Antiquity Publications Ltd. 
SIEvers, S. 2010. Vom Fürstensitz zum Oppidum, in D. Krausse (ed.) "Fürstensitze" und Zentralorte der frühen Kelten (Forschungen und Berichte zur Vorund Frühgeschichte in Baden-Württemberg 120): 31-34. Stuttgart: Konrad Theiss.

Sievers, S. \& M. SCHÖNFELDER (ed.). 2012. Die Frage der Protourbanisation in der Eisenzeit. Bonn: Habelt.

SMITH, M.E. 2007. Form and meaning in the earliest cities: a new approach to ancient urban planning. Journal of Planning History 6(1): 3-47.

-2010 . The archaeological study of neighborhoods and districts in ancient cities. Journal of Anthropological Archaeology 29: 137-54.
Stegmaier, G. 2010. Zur Entstehung, Datierung und Besiedlung der Heuneburg-Vorburg. Ergebnisse der Grabungen 2000 bis 2003, in D. Krausse (ed.) "Fürstensitze" und Zentralorte der frühen Kelten (Forschungen und Berichte zur Vor- und Frühgeschichte in Baden-Württemberg 120): 257-68. Stuttgart: Konrad Theiss.

VERGER, S. 2008. Enterré dans le souvenir de la maison. A propos du tumulus 4 de la Heuneburg dans la haute vallée du Danube, in G. Bartoloni \& M.G. Benedettini (ed.) Sepolti tra i vivi. Evidenza ed interpretazione di contesti funerari in abitato (Scienze dell'Antichità 14): 919-58. Rome: Quasar.

WELLS, P.S. 1984. Farms, villages and cities: commerce and urban origins in late prehistoric Europe. Ithaca (NY): Cornell University Press.

Received: 24 July 2012; Accepted: 28 September 2012; Revised: 5 November 2012

(C) Antiquity Publications Ltd. 